\title{
PENGARUH PENATAAN TEMPAT DUDUK TERHADAP HASIL BELAJAR SISWA PADA PEMBELAJARAN IPA KELAS V SD N 20 KOTA BENGKULU
}

\author{
Yopika Lestari \\ Universitas Bengkulu \\ E-mail: Yopikalestari12@yahoo.com
}

Rohiat

Universitas Bengkulu

Dwi Anggraini

Universitas Bengkulu

\begin{abstract}
Abstrak
Penelitian ini bertujuan untuk mengetahui pengaruh penataan tempat duduk terhadap hasil belajar aspek kognitif, afektif dan psikomotor siswa pada pembelajaran IPA kelas V SD N 20 Kota Bengkulu. Jenis penelitian adalah kuantitatif dengan metode penelitian eksperimen semu. Desain yang digunakan the matching only pretest-posttest control group design. Sampel penelitian ini adalah siswa kelas VA sebagai kelas kontrol dan VB sebagai kelas eksperimen. Sampel penelitian ditentukan dengan menggunakan cluster random sampling. Uji coba instrumen dilakukan pada siswa kelas VIB SD N 20 Kota Bengkulu. Instrumen yang digunakan lembar tes dan lembar observasi aspek afektif dan psikomotor. Untuk mengamati perlakuan yang diberikan oleh guru instrumen yang digunakan lembar observasi penataan tempat duduk. Teknik analisis data yang digunakan teknik analisis kuantitatif menggunakan uji-t dua sampel independent. Hasil uji hipotesis diperoleh uji-t kognitif yaitu thitung $(14,052)>$ ttabel $(1,671)$, uji-t afektif yaitu thitung $(-3,27)<(1,671)$, dan uji-t psikomotor yaitu thitung $(0,633)<(1,671)$. Maka dapat disimpulkan bahwa: (1) Terdapat pengaruh penataan tempat duduk terhadap hasil belajar siswa aspek kognitif pada pembelajaran IPA kelas V SD N 20 Kota Bengkulu, (2)Tidak terdapat pengaruh penataan tempat duduk terhadap hasil belajar siswa aspek afektif pada pembelajaran IPA kelas V SD N 20 Kota Bengkulu, (3) Tidak terdapat pengaruh penataan tempat duduk terhadap hasil belajar siswa aspek psikomotor pada pembelajaran IPA kelas V SD N 20 Kota Bengkulu.
\end{abstract}

Kata kunci: Penataan Tempat Duduk, Pembelajaran IPA, Hasil Belajar.

\section{PENDAHULUAN}

Guru sebagai seorang pendidik harus mampu menata lingkungan fisik kelas dengan baik. Melalui penataan kelas yang tepat maka akan tercipta suasana belajar yang kondusif, selain itu siswa juga akan mendapat dorongan dan rangsangan untuk lebih semangat dalam mengikuti proses pembelajaran. Penataan lingkungan fisik kelas dapat berupa penataan tempat duduk. Tetapi pada kenyataannya, penataan tempat duduk yang dilakukan oleh guru masih belum maksimal. Penataan tempat duduk merupakan salah satu faktor pendukung dalam mencapai keberhasilan belajar. Hal ini sejalan dengan pendapat Winzer dalam Anitah (2011: 10.17) bahwa penataan lingkungan kelas yang tepat berpengaruh terhadap tingkat keterlibatan dan partisipasi siswa dalam proses pembelajaran. Lebih jauh, diketahui bahwa tempat duduk berpengaruh terhadap waktu yang digunakan siswa untuk menyelesaikan tugas yang diberikan. Semakin tepat penataan tempat duduk yang dilakukan guru, semakin banyak waktu yang digunakan siswa untuk mengerjakan tugas yang diberikan sehingga 
siswa berperan aktif dalam proses pembelajaran. Sesuai dengan teori belajar Bruner dalam Slameto (2013: 11) bahwa dalam proses belajar mementingkan pastisipasi aktif dari setiap siswa. Penataan tempat duduk yang tepat terutama pada kegiatan kelompok akan meningkatkan keaktifan dan kreatifitas siswa dalam proses pembelajaran sehingga juga akan berpengaruh terhadap hasil belajar siswa itu sendiri. Sejalan dengan pendapat Ruhimat (2010: 140) yang mengatakan bahwa faktor lingkungan fisik berpengaruh terhadap hasil belajar siswa. Pengaturan lingkungan fisik kelas dengan melakukan penataan tempat duduk.

Pembelajaran IPA memiliki banyak kegiatan baik itu secara individual maupun secara kelompok. Menurut Winaputra dalam Samatowa (2010: 3) IPA tidak hanya merupakan kumpulan pengetahuan tentang benda atau makhluk hidup tetapi memerlukan kerja, cara berpikir, dan cara memecahkan masalah. Itu berarti dalam pembelajaran IPA selain tugas individual, siswa juga harus melakukan kerja kelompok misalnya berupa percobaan sehingga siswa dilatih untuk berpikir kritis dalam memecahkan suatu masalah secara bersama-sama dalam proses pembelajaran. Siswa akan lebih aktif dalam pembelajaran IPA jika penataan tempat duduk yang dilakukan dengan menggunakan penataan tempat duduk setengah lingkaran yang disesuaikan dengan kegiatan dan materi dalam proses pembelajaran.

Pada saat pra penelitian tepatnya pada bulan November, peneliti melakukan pengamatan di SD N 20 Kota Bengkulu dan menemukan permasalahan yaitu (1) Penataan tempat duduk yang bersifat monoton yaitu dalam bentuk berbaris ke belakang; (2) Tidak pernah ada perubahan penataan tempat duduk yang dilakukan guru sehingga siswa merasa bosan dan sering ribut ketika pelaksanaan pembelajaran terutama pada pembelajaran IPA yang memiliki banyak kegiatan tetapi pada kenyataannya guru hanyal bertindak untuk menyampaikan materi sedangkan penataan tempat duduk kurang diperhatikan contohnya ketika melakukan diskusi kerja kelompok, siswa tetap berada pada posisi tempat duduknya dan tidak mengatur letak meja dan kursi selayaknya kerja kelompok;

Kurangnya perhatian guru mengenai halhal yang dianggap penting dalam penataan tempat duduk, misalnya komposisi siswa ketika membagi siswa ke dalam suatu kelompok.

Padahal ada beberapa bentuk penataan tempat duduk yang dapat digunakan guru sebagai alternatif lain dalam mengelola lingkungan fisik kelas. Melalui penataan tempat duduk setengah lingkaran, siswa tidak merasa bosan dalam pembelajaran dan akan merasa nyaman serta lebih leluasa dalam belajar. Dengan terciptanya iklim belajar yang kondusif dan menyenangkan maka akan membangkitkan semangat dan menumbuhkan aktivitas serta kreativitas siswa. Siswa juga akan lebih memfokuskan diri dalam mengikuti proses pembelajaran, terutama ketika guru melakukan proses pembelajaran dengan diskusi kelompok. Berdasarkan permasalahan dan didukung dengan hasil penelitian sebelumnya, peneliti tertarik untuk mengambil judul penelitian “ Pengaruh penataan tempat duduk terhadap hasil belajar siswa pada pembelajaran IPA kelas V SD N 20 Kota Bengkulu”.

Berdasarkan latar belakang di atas, maka rumusan masalah dalam penelitian ini (1) Apakah terdapat pengaruh penataan tempat duduk terhadap hasil belajar aspek kognitif siswa pada pembelajaran IPA kelas V SD N 20 Kota Bengkulu ?; (2) Apakah terdapat pengaruh penataan tempat duduk terhadap hasil belajar aspek afektif siswa pada pembelajaran IPA kelas V SD N 20 Kota Bengkulu ?; (3) "Apakah terdapat pengaruh penataan tempat duduk terhadap hasil belajar aspek psikomotor siswa pada pembelajaran IPA kelas V SD N 20 Kota Bengkulu?.

Berdasarkan rumusan masalah di atas, maka tujuan penelitian ini adalah (1) untuk mengetahui pengaruh penataan tempat duduk terhadap hasil belajar aspek kognitif siswa pada pembelajaran IPA kelas V SD N 20 
Kota Bengkulu; (2) untuk mengetahui pengaruh penataan tempat duduk terhadap hasil belajar aspek afektif siswa pada pembelajaran IPA kelas V SD N 20 Kota Bengkulu; (3) untuk mengetahui pengaruh penataan tempat duduk terhadap hasil belajar aspek psikomotor siswa pada pembelajaran IPA kelas V SD N 20 Kota Bengkulu.

\section{METODE}

Jenis penelitian ini adalah penelitian eksperimen semu, penelitian yang digunakan untuk mencari pengaruh perlakuan tertentu terhadap yang lain dalam kondisi yang terkendali

Populasi dalam penelitian ini adalah seluruh siswa kelas V SD N 20 Kota Bengkulu. Sampel penelitian ini adalah siswa kelas VA sebagai kelas kontrol dan VB sebagai kelas eksperimen

Instrumen yang digunakan dalam penelitian ini adalah lembar tes dan observasi. Teknik pengumpulan data dalam penelitian ini melalui tes, observasi dan dokumentasi hasil belajar siswa. Data yang diperoleh akan dianalisis menggunakan uji test menggunakan rumus pooled varian yang bertujuan untuk melihat apakah terdapat pengaruh hasil belajar siswa yang signifikan antara kelas eksperimen dan kelas kontrol.

\section{HASIL}

Berdasarkan hasil analisis uji normalitas setiap sampel dengan kriteria jika $X^{2}$ hitung $<\chi^{2}$ tabel

Hasil uji normalitas hasil belajar aspek kognitif kelas eksperimen dan kelas kontrol.

\begin{tabular}{|l|c|c|l|}
\hline Kelompok & $\chi_{\text {hiturg }}^{2}$ & $\chi_{\text {tabel }}^{2}$ & \multicolumn{1}{|c|}{$\begin{array}{r}\text { Distribusi } \\
\text { data }\end{array}$} \\
\hline Eksperimen & 9,6 & \multirow{2}{*}{11,070} & Normal \\
\cline { 1 - 2 } Kontrol & 8,0 & & Normal \\
\hline
\end{tabular}

Setelah dilakukan uji normalitas selanjutnya dilakukan uji homogenitas dengan kriteria jika $\mathrm{F}$ hit ung $<\mathrm{F}_{\text {tabel }}$ maka kedua sampel homogen. Hasil uji homogenitas kedua sampel yaitu Fhit tung 1,302 < Ftabel 1,80 maka data homogen.

Setelah dilakukan uji normalitas dan homogenitas, maka dilakukan uji hipotesis untuk melihat apakah terdapat pengaruh hasil belajar siswa yang signifikan pada aspek kognitif antara siswa yang menggunakan penataan tempat duduk setengah lingkaran dan siswa yang menggunakan penataan tempat duduk secara konvensional. Dengan ketentuan jika $\chi^{2} h i t_{\text {ung }}>\chi_{2 \text { tabel }}$ maka Ha diterima. Hasil analisis uji hipotesis menunjukan $\chi 2$ hitung $14,061>\chi 2$ tabel 1,671 yang artinya Ha diterima. Artinya terdapat pengaruh hasil belajar siswa yang signifikan pada aspek kognitif antara siswa yang menggunakan penataan tempat duduk setengah lingkaran dan siswa yang $\chi 2$ hitung $3,27<\chi 2$ tabel 1,671 yang artinya Ha ditolak. Artinya tidak terdapat pengaruh hasil belajar siswa yang signifikan pada aspek afektif antara siswa yang menggunakan

penataan tempat duduk setengah lingkaran dan siswa yang menggunakan penataan tempat duduk secara konvensional.

Hasil uji normalitas hasil belajar aspek psikomotor kelas eksperimen dan kelas kontrol.

\begin{tabular}{|l|c|c|c|}
\hline Kelompok & $\begin{array}{c}X \\
{ }^{2} \text { hitung }\end{array}$ & $X^{2}$ tabel & $\begin{array}{c}\text { Distribusi } \\
\text { data }\end{array}$ \\
\hline Eksperimen & 5,1 & \multirow{2}{*}{11,070} & Normal \\
\cline { 1 - 2 } Kontrol & 10,7 & & Normal \\
\hline
\end{tabular}

Setelah dilakukan uji normalitas selanjutnya dilakukan uji homogenitas dengan kriteria jika $\mathrm{F}$ hit $t_{\text {ung }}<\mathrm{F}_{\text {tabel }}$ maka kedua sampel homogen. Hasil uji homogenitas kedua sampel

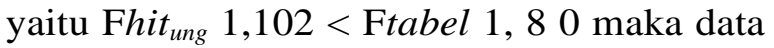
homogen. Setelah dilakukan uji normalitas dan homogenitas, maka dilakukan uji hipotesis untuk melihat apakah terdapat pengaruh hasil menggunakan penataan tempat duduk secara konvensional.

Hasil uji normalitas hasil belajar aspek afektif kelas eksperimen dan kelas kontrol.

\begin{tabular}{|c|c|c|}
\hline Kelompok $X^{2}$ hitung & $X^{2}$ tabel & $\begin{array}{c}\text { Distribusi } \\
\text { data }\end{array}$ \\
\hline Eksperimen 8,0 & \multirow{2}{*}{11,070} & Normal \\
\hline \begin{tabular}{|l|l|} 
Kontrol & 4,7
\end{tabular} & & Normal \\
\hline
\end{tabular}


Setelah dilakukan uji normalitas selanjutnya dilakukan uji homogenitas dengan kriteria jika Fhitung < Ftabel maka kedua sampel homogen. Hasil uji homogenitas kedua sampel yaitu Fhitung 1,078 < Ftabel 1,80 maka data homogen.

Setelah dilakukan uji normalitas dan homogenitas, maka dilakukan uji hipotesis untuk melihat apakah terdapat pengaruh hasil belajar siswa yang signifikan pada aspek afektif antara siswa yang menggunakan penataan tempat duduk setengah lingkaran dan siswa yang menggunakan penataan tempat duduk secara konvensional.

Dengan ketentuan jika $\chi^{2}$ hitung $>\chi^{2}$ tabel maka Ha diterima. Hasil analisis uji hipotesis menunjukan belajar siswa yang signifikan pada aspek psikomotor antara siswa yang menggunakan penataan tempat duduk setengah lingkaran dan siswa yang menggunakan penataan tempat duduk secara konvensional.

Dengan ketentuan jika $\chi^{2}$ hitung $>\chi^{2}$ tabel maka Ha diterima. Hasil analisis uji hipotesis menunjukan $\chi^{2}$ hitung $0,633<\chi^{2}$ tabel 1,671 yang artinya Ha ditolak. Artinya tidak terdapat pengaruh hasil belajar siswa yang signifikan pada aspek psikomotor antara siswa yang menggunakan penataan tempat duduk setengah lingkaran dan siswa yang menggunakan penataan tempat duduk secara konvensional.

\section{PEMBAHASAN}

Berdasarkan hasil penelitian terdapat pengaruh hasil belajar siswa yang signifikan pada aspek kognitif antara siswa yang menggunakan penataan tempat duduk setengah lingkaran dan siswa yang menggunakan penataan tempat duduk secara konvensional. Dengan penataan tempat duduk setengah lingkaran siswa dapat lebih leluasa dalam bergerak dan menumbuhkan keaktifan siswa dalam proses pembelajaran tanpa adanya gangguan karena siswa lebih terfokus pada kelompok masing-masing. Dalam pembelajaran IPA, ketika melakukan percobaan siswa lebih berperan aktif dan lebih terfokus pada siswa dalam kegiatan pembelajaran karena melalui percobaan siswa secara langsung melakukan sesuatu untuk memecahkan suatu masalah. Menurut Piaget dalam Samatowa (2010: 5) yang mengatakan bahwa pengalaman langsung yang memegang peranan penting sebagai pendorong lajunya perkembangan kognitif anak.

Hasil penelitian pada aspek afektif yaitu tidak terdapat pengaruh hasil belajar siswa yang signifikan pada aspek afektif antara siswa yang menggunakan penataan tempat duduk setengah lingkaran dan siswa yang menggunakan penataan tempat duduk secara konvensional. Pada saat proses pembelajaran berlangsung ada tiga sikap ilmiah IPA yang diamati yaitu sikap bertanggung jawab, rasa ingin tahu, dan bekerja sama. Pada kelas eksperimen maupun kelas kontrol siswa menunjukkan perubahan sikap yang awalnya kurang menjadi lebih peduli terhadap apa yang ada di sekelilingnya meskipun tidak secara keseluruhan. Menurut Winarni (2012: 155) sikap merupakan salah satu unsur kepribadian yang harus dimiliki seseorang untuk menentukan tindakan dan bertingkah laku terhadap suatu objek yang disertai dengan perasaan, penerimaan atau penolakan.

Sedangkan hasil penelitian pada aspek psikomotor yaitu tidak terdapat pengaruh hasil belajar siswa yang signifikan pada aspek psikomotor antara siswa yang menggunakan penataan tempat duduk setengah lingkaran dan siswa yang menggunakan penataan tempat duduk secara konvensional. Pada saat proses pembelajaran berlangsung ada tiga aspek psikomotor siswa yang diamati yaitu penggunaan alat-alat percobaan, penulisan laporan, dan menyajikan hasil percobaan. Pada kelas eksperimen maupun kelas kontrol siswa menunjukkan kemampuan diri agar terlihat bisa meskipun tidak secara keseluruhan. Hasil belajar ranah psikomotor yang dilihat pada penelitian ini terdiri dari tiga aspek yaitu memanipulasi, pengalamiahan, dan artikulasi sesuai dengan kata kerja 
operasional pada setiap deskriptornya

\section{SIMPULAN}

Berdasarkan analisis hasil penelitian di SD N 20 Kota Bengkulu dapat disimpulkan bahwa terdapat pengaruh hasil belajar siswa yang signifikan pada aspek kognitif antara siswa yang menggunakan penataan tempat duduk setengah lingkaran dan siswa yang menggunakan penataan tempat duduk secara konvensional. Sedangkan aspek afektif dan psikomotor tidak terdapat pengaruh hasil belajar siswa yang signifikan antara siswa yang menggunakan penataan tempat duduk setengah lingkaran dan siswa yang menggunakan penataan tempat duduk secara konvensional.

\section{SARAN}

Berdasarkan hasil penelitian yang dilakukan, maka peneliti mengemukakan lima saran yaitu sebagai berikut:

1. Pemilihan penataan tempat duduk yang digunakan harus disesuaikan dengan metode yang akan digunakan dalam proses pembelajaran.

2. Hendaknya dalam proses pembelajaran tidak hanya kognitifnya saja yang ditekankan, tetapi sikap dan keterampilan siswa juga perlu diperhatikan.

3. Penataan tempat duduk setengah lingkaran akan lebih efektif digunakan dalam pembelajaran keterampilan yang menggunakan kegiatan kerja kelompok.

4. Penataan tempat duduk bervariasi akan meningkatkan partisipasi aktif siswa sehingga proses pembelajaran lebih

5. berpusat kepada siswa yang secara otomatis dapat berpengaruh pada hasil belajar siswa itu sendiri.

6. Untuk meningkatkan hasil belajar afektif dan psikomotor, dapat dilakukan dengan menggunakan penataan tempat duduk lainnya yang sesuai dengan materi dalam pembelajaran.

\section{DAFTAR PUSTAKA}

Anitah, Dkk. 2007. Strategi Pembelajaran di SD. Jakarta: Universitas Terbuka.

Ruhimat, Toto. 2011. Kurikulum dan Pembelajaran. Jakarta: PT Raja Grafindo Persada.

Samatowa, Usman. 2010. Pembelajaran IPA di Sekolah Dasar. Jakarta: PT Indeks.

Slameto. 2013. Belajar dan Faktor-Faktor Yang Mempengaruhi. Jakarta: Rineka Cipta.

Winarni, Endang Widi. 2012. Inovasi Dalam Pembelajaran IPA. Bengkulu: FKIP UNIB. 